\title{
Delphi Expert Survey on Climate Policies, Plans/Strategies in Nepal
}

\author{
Shree K. Maharjan * and Keshav L. Maharjan
}

Graduate School for International Development and Cooperation, Hiroshima University, 1-5-1 Kagamiyama Higashi Hiroshima, 739-8529 Japan

* Corresponding author, $\underline{\mathrm{d} 171286 @ \text { hiroshima-u.ac.jp }}$

\begin{abstract}
The government of Nepal (GoN) has developed and implemented climate policies, plans and frameworks such as NAPA, National Climate Change Policy, LAPA and currently in the process of developing National Adaptation Plans (NAPs). These policies and plans are in different states of its implementation with diverse opinions and perceptions of the stakeholders. The paper has explored these opinions and experiences of climate experts in Nepal on state of climate policies, inter-linkages, roles and responsibilities of ministries/departments, important factors and subjective indicators for effective implementation of the policies. Altogether 30 experts responded the questionnaire sent via the email, LinkedIn and Skype Interview in the $1^{\text {st }}$ phase of Delphi research technique. The experiences of these experts range from 2-30 years representing government, non-government sectors, media and independent experts. As per most of the experts interviewed, the policies and plans are progressing in strategic direction with national and local priorities. The LAPA is the pioneer framework to address the local climatic issues, originated in Nepal. However, lack of clarity on roles/responsibilities and coordination among the ministries/departments; clear mechanisms for implementation of these policies; lack of sensitization, decentralization and delegation of finance and technologies; capacity of the stakeholders are the major challenges identified.
\end{abstract}

Keywords: climate policy; Nepal; NAPA; LAPA; climate experts

\section{Introduction}

Nepal is identified as the vulnerable country to the climate change impacts since large number of population and their livelihoods are principally dependent on climate sensitive sectors such as rain-fed agriculture, forestry and related economies $[1,2,3]$. Climate change is seen as an undesirable reality with its impacts mostly faced by the poor and marginalized communities living in the rural areas of Nepal [4]. Moreover, Nepal is severely prone to climate induced disasters like flood, drought, glacier lake outbursts, cold waves and others due to its fragile ecology, rugged topography, weak political and institutional aptitude and the least adaptive capacity of the people. Thus, it is highly affected by the negative consequences of 
climate change though it has negligible contributions to global greenhouse gas emissions $[5,6]$. It is ranked as the $4^{\text {th }}$ most vulnerable country in the world, next to Bangladesh, India and Madagascar as per the risk analysis done in 2011 by the Maplecroft based on the vulnerability index with extreme risk of climate change impacts for next 30-years considering poverty, adaptive capacity and high dependence on natural resources $[7,8]$.

Changes and impacts of climate change have been observed by climate experts and even communities over the years [5]. It has been forecasted that the impacts will be increased in decades to come. Malla [1] revealed the increase of temperature by $1.8^{\circ}$ $\mathrm{C}$ for last 32 years with the annual increase of $0.06^{\circ} \mathrm{C}$. The impacts of climate change cannot be completely controlled, however, effective adaptation and mitigation policies, plans and strategies can lower the climate change impacts and climate induced disasters. Climate change has long term negative impacts on agriculture and farmers' livelihoods. Thus, urgent and long terms actions on adaptation are needed at individual and community levels for securing livelihoods. Despite long climate change negotiation and policy debates, few concrete actions are taking place in the ground [4]. Furthermore, Ojha et al. [9] emphasized on integration of voices of vulnerable peoples into the policy debates and framing climate policies.

Climate change researches in Nepal are more focused on assessments of vulnerabilities and adaptation practices. Only handful research has focused on climate policies. Most probably, climate change policy is the newest addition to Nepal's legislative framework [23], despite the government and non-government organizations have been commencing adaptation initiatives in Nepal for decades [2]. Correspondingly, the communities have been coping with the impacts through their own efforts and initiatives based on their knowledge, practices and experiences. The government of Nepal (GoN) have formulated climate policies and plans such as National adaptation programme of action (NAPA), local adaptation plan of action (LAPA), National climate change policy to address the climate risks and hazards [10]. Most of the policies and strategies development process was led by Ministry of Population and Environment (MoPE). The GoN is currently in the process of formulating National Adaptation Plan (NAP) to identify and prioritize mid to long term adaptation actions to address the climate change concerns in the national planning and decision making process [3]. These policies have highlighted the adaptation practices and frameworks from the national to local levels [2]. The climate experts, government and non-government organizations, communities have contributed in the process of formulation and implementation of adaptation plans and policies [10].

This paper explores and analyzes the views, observations and experiences of climate experts mainly on climate change policies, plans/strategies, frameworks and their interlinkages. It further analyzes the roles and responsibilities of ministries and departments including the factors affecting implementation of policies, 
plans/strategies and frameworks. Additionally, the paper analyses the subjective indicators for effective implementation of the policies, plans and frameworks.

\section{Methodology}

The study has adopted the Delphi expert survey with the selected climate experts in Nepal. Prior to develop the questionnaire, an extensive review of the papers and policies related to climate change was done in Nepalese context. The review eased to develop subjective questionnaire on the state of climate change policies and plans/strategies in Nepal, the inter-connections between the policies and plans/strategies including the roles and responsibilities of agencies involved, factors affecting and subjective indicators for effective implementation in Nepal.

The list of climate experts was generated from the NGO group on climate change (NGOCC), which is a loose network of climate experts in Nepal that aims for building and strengthening a strong network and alliance by engaging in climate change research and development work in the country. The member of this group are representatives of civil society organizations including representatives of INGOs, donors and the government organizations as the advisors. This network serves as the learning and information sharing platform among the climate experts, the practitioners and also for NGOs working at grass root level [11].

Altogether 53 climate experts were identified purposively for the survey based on their continuous contributions and engagements in climate change debates and negotiations at the national and international levels. The experts were approached by email, Skype and LinkedIn and Research gate messenger. But only 30 experts responded the questionnaire via the email communication and Skype Interview, despite their busy time schedule. Only $10 \%$ of the respondents are female, which indicates that climate change policy discourse is highly male dominant phenomenon in Nepal. Interestingly, most of the climate change experts in Nepal has completed at least Masters level of education, but in different fields ranging from forestry, agriculture, environment management, science in general, arts, anthropology, health and others. The experiences of the experts ranges from 2 to 30 years of work in the climate change sector both representing government and non-government sectors including media, private and independent experts. Very few experts (only $5 \%)$ experts have less than 5 years of experiences, whereas maximum experts $(62 \%)$ have their work experiences ranged from 6-10 years. In terms of their affiliations, Governments, International Non-Governmental Organizations (INGOs) and Civil Society Organizations (CSOs) represented 19\% in the survey. In addition, there are representatives of Media (4\%), Donors (4\%), Indigenous people's organizations (IPOs) (8\%), research and academics (12\%) and independent experts (15\%). All the subjective responses of the experts were analyzed thoroughly to generate the results of the survey. 

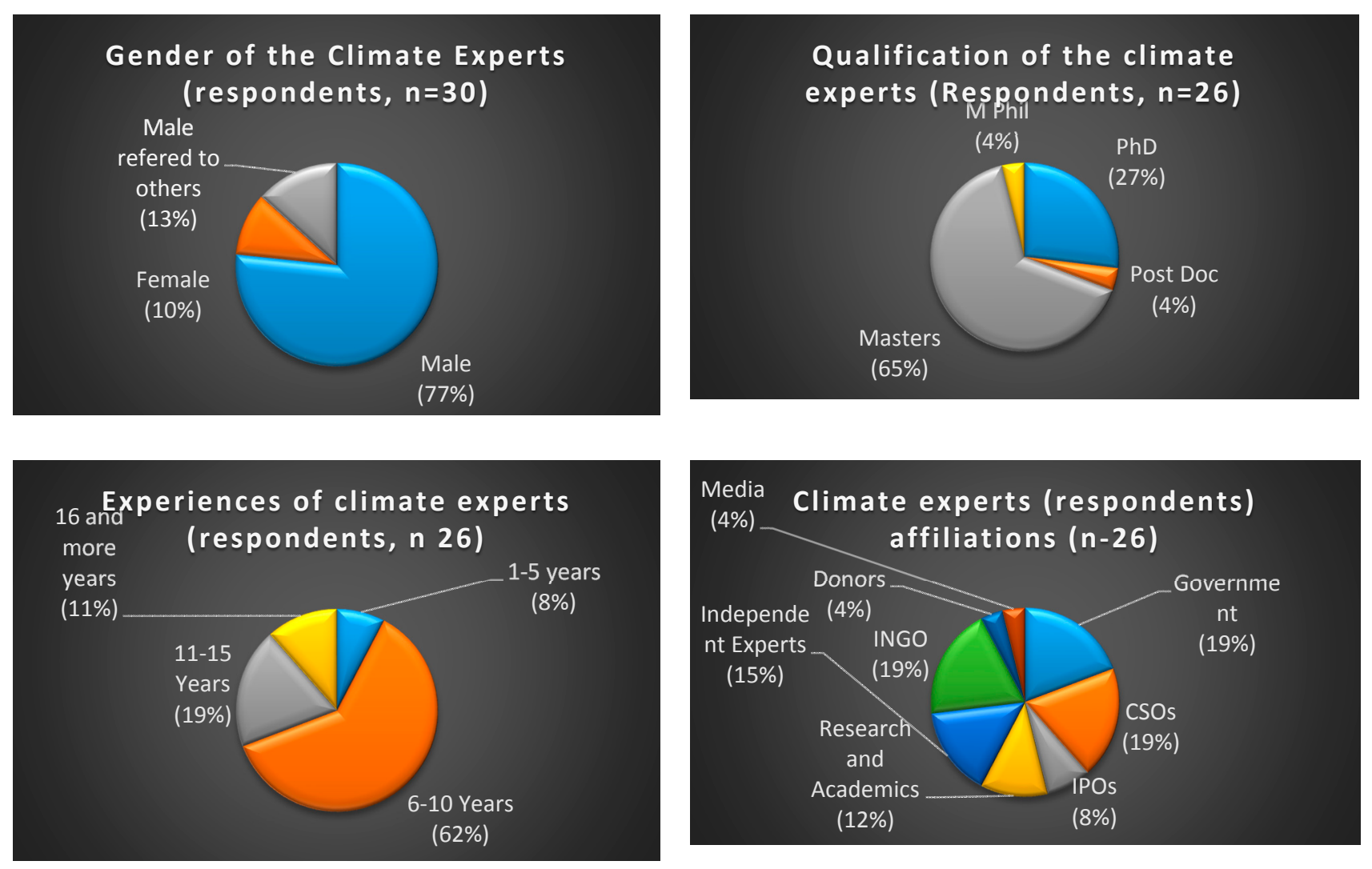

Figure 1: Composition of climate experts (respondents) in the expert opinion survey

\section{Results and discussion}

\subsection{Interrelationship between climate policies, plans, frameworks and strategies}

Most of the experts believed that climate policies and plans are advancing well in Nepal. Most of these policies, plans, strategies and frameworks are in the hierarchical order (figure 2). The policies are the goals and objectives that set the rules on climate change adaptation and mitigation at national level. The plans and strategies are long term roadmap to achieve the goals and objectives based on the set of rules defined by the policies. Likewise, the frameworks are step by step process to implement the plans and strategies as guided by the policies. Based on policies, plans/strategies and frameworks, the short and medium term projects are developed and implemented accordingly. Most of the experts agreed on this relationship of the policies, plans/strategies, frameworks and projects. For instance, climate change policy is the overarching set of rules in climate change discourse in Nepalese context that guides NAP, NAPA and LAPA for long, medium and short term plans/strategies and framework to fulfill the immediate and urgent needs and priorities. Policy is the instrument formally facilitate and guide research and development, whereas plans/strategies are supportive instruments to implement policy provisions. On the other hand, it is important to assess and understand local climate change vulnerabilities, risks and impacts to develop and implement the local adaptation policies [23]. 


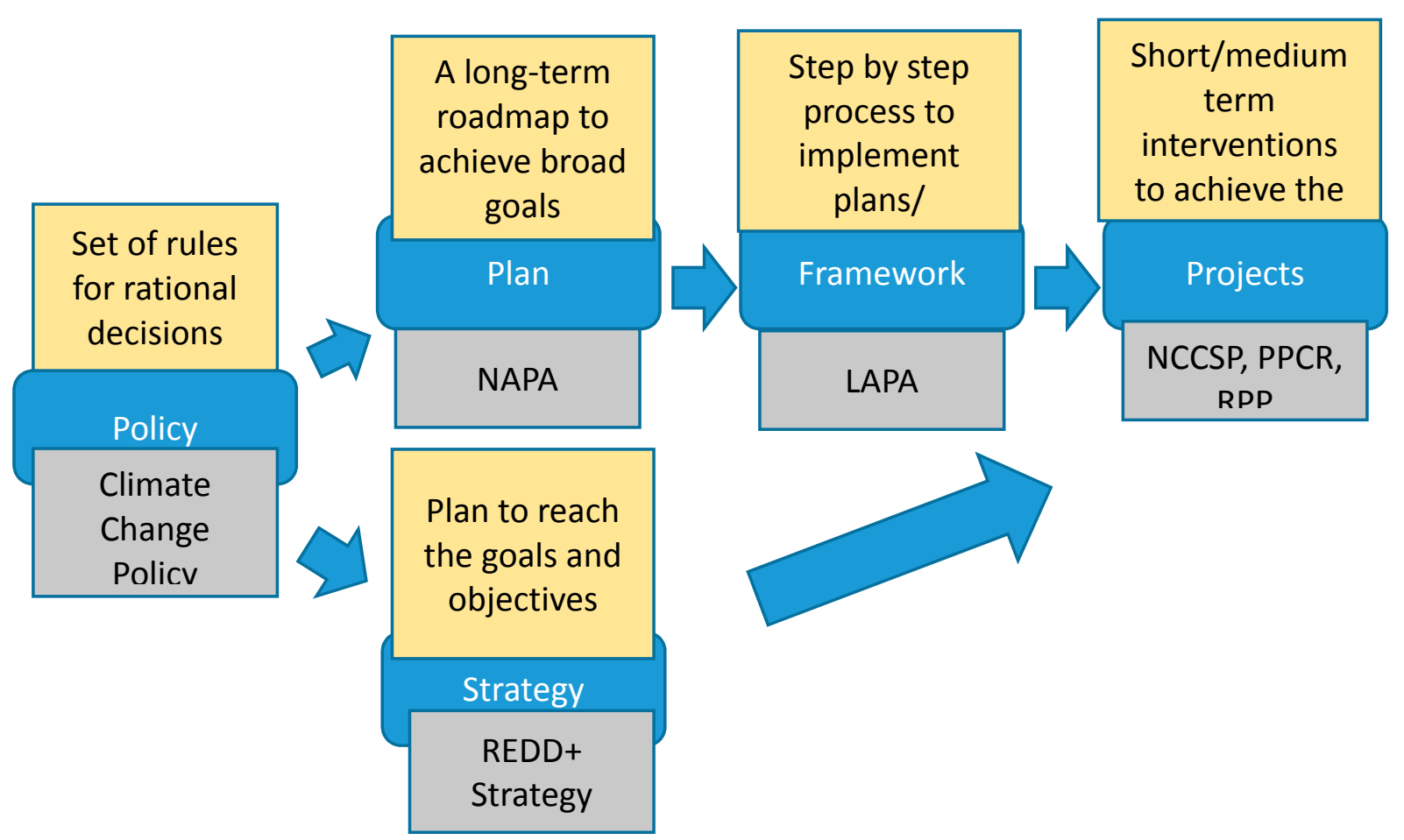

Figure 2: Relationships between climate policy, plans, strategies, frameworks and projects in Nepalese context

Note: NAPA - National Adaptation Programme of Action, LAPA - Local Adaptation Plan of Action, REDD+ - Reducing Emission from Deforestation and forest Degradation, conservation and sustainable management of forests and enhancement of forest carbon stocks in developing countries, NCCSP - Nepal Climate Change Support Programme, PPCR Pilot Program on Climate Resilience.

Edvardsen [12] agreed on the hierarchical order of planning process in the form of policy-program-project, which he defined as the Chinese box model of planning. He also emphasized on the national level plan which establishes the basis for the regional and local level plans in the form of macro level plans to meso-level and ultimately to micro level plans (Figure 3). In theory, every plan should guide the next level plan, however in practice it is not always possible. For instance, NAPA was formulated in 2010 in Nepal prior to the national climate change policy that was formulated a year after only. In that sense, it didn't follow the hierarchical order. The plan was prepared in advance to the policy. It was because of the time pressure of the GoN to submit the NAPA to the United Nations Framework Convention on Climate Change (UNFCCC) within given timeframe, which was also criticized by many experts and literatures also supported particularly on climate policies and plans/strategies driven by international climate agreements and negotiations rather than fulfilling the local and national needs and priorities regarding climate change. However, climate policy has been centrally important for the rural vulnerable communities to ensure the optimum benefits [23]. But it is still an issues raised by some of the experts that limited experts are involved in the process of policy formulation. The voices of the rural, poor and vulnerable communities are not reflected in the policies, plans and strategies [9]. 

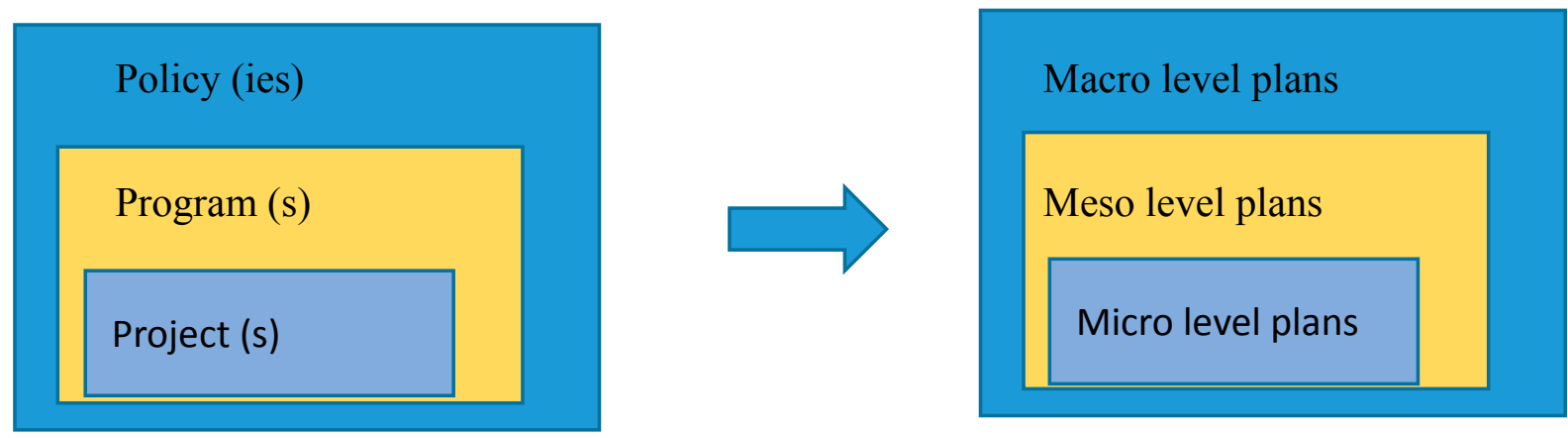

Figure 3: The relationship between polic(ies), program(s) and project(s) at different levels as defined by Edvardsen [12]

Nevertheless, most of the experts agreed that there are positive linkages between national climate change policy, NAPA and LAPA framework. Peniston [13] and Maharjan \& Maharjan [10] also supported on the advanced linkages in their papers as LAPA framework was developed to mainstream the local adaptation needs into development planning as guided by NAPA and national climate change policy. It is a central issue to integrate the climate change adaptation and adaptive capacity within the development processes, policies and practices. The policy has to link, integrate and interlink across the scales and levels such as local, regional, national and international levels. Thus, it is crucial to understand all the issues to integrate the programmes and implementation [23]. Furthermore, Peniston [13] believed that LAPA is an effective instrument to implement NAPA priority programmes through effective and immediate delivery of adaptation services. Both of the plans have given emphasis on $80 \%$ of the available budget for the local level implementation of identified adaptation actions.

However, 2 experts argued for lack of systematic connection between policies, plans/strategies and framework in Nepal. They argued that lack to connection of these plans/strategies and frameworks to the overall development, disaster risk reduction and practical integration. Helvetas Nepal [8] reinforced their views in its paper by highlighting the lack of technical aspects of climate variability, vulnerability and projections, especially on climate change policy, as integral parts of climate change adaptation and mitigation measures. Furthermore, Regmi \& Bhandari [4] also pointed out that Nepalese climate policy at current state lacks technicality on vulnerable assessment and effective implementation including the community awareness, orientation and financial security.

\subsection{State of climate change policies, plans, strategies and frameworks in Nepal}

The GoN has formulated number of climate change policies, plans/strategies and frameworks such as NAPA, LAPA, national climate change policy, low carbon economic development strategy (LCEDS), Clean Development Mechanism (CDM), National REDD+ strategy, disaster risk reduction strategies, NAP (in process) at 
national and local levels. All of these policies, plans, frameworks and strategies are in different states of implementation and successes. But, national climate change policy, NAPA, LAPA and NAP are familiar to more than $95 \%$ of the experts. The reason was most of the experts were engaged in the consultation process and contributed in the formulation process. Additionally, GoN has given more emphasized on the adaptation policies in Nepal. Tiwari et al., [2] also emphasized that adaptation policies are important for Nepal, especially for the rural communities to address the local climatic issues at the grass root levels.

In contrary, only few experts (5\%) have mentioned low carbon economic development strategy (LCEDS), National REDD+ Strategy and other sectoral policies and strategies that has specific focuses. These sectoral policies, plans/strategies were led by the sectoral ministries. These policies have specific and sectoral focus either on energy and forestry, whereas the UNFCCC compliance policy report documents such and Initial national communication (INC), second national communication (SNC) have provided some good basis for the progresses on the policies. Many experts expressed the necessity of the GoN to focus on specific and sectoral policies and mainstream climate change into the sectoral policies and plans, as some have already started such as REDD+ strategy and LCEDS.

The experts also stated the number of climate change related programmes/projects implemented by the government such as Pilot Programme for Climate Resilience (PPCR), 2010; Poverty-Environment Initiatives (PEI), 2010; Climate Adaptation Design Project-Nepal (CADP-N), 2010; REDD Readiness Project (2010-2013), Nepal Climate Change Support Programme (NCCSP), 2015 with the funding supports of different donors in line with the policies, plans/strategies and frameworks (table 1). The experts also revealed that most of these programmes/projects have specific focuses to be implemented in collaboration with different ministries and departments, which they believe crucial for the success, however it is very difficult in reality. The GoN has acclaimed the effective collaboration and cooperation among the stakeholders in the process of formulating the climate policies, strategies/plans [14], which is also supported by Tiwari et al., [2] by revealing the participatory, inclusive, flexible and responsive process. However, Regmi \& Bhandari [4] and Sherpa et al., [15] strongly criticized the effective collaboration and participation in the process. They further raised the issue of effective collaboration in the implementation process.

Table 1. Climate related Policies, Plans and Strategies in Nepal

\begin{tabular}{|c|l|}
\hline S. N. & \multicolumn{1}{c|}{ Policies, plans and strategies in Nepal } \\
\hline \multicolumn{2}{|c|}{ Governance and Institutional Policies } \\
\hline 1. & Local Self-Governance Act (LSGA), 1999 \\
\hline 2. & Nepal Interim Constitutions, 2007 \\
\hline 3. & Three-Year Interim Plan, 2007 \\
\hline
\end{tabular}




\begin{tabular}{|c|l|}
\hline 4. & $\begin{array}{l}\text { Local Governance and Community Development Programme (LGCDP), } \\
2008\end{array}$ \\
\hline 5. & Three-Year Plan Approach Paper, 2010 \\
\hline 6. & Environment Friendly Local Governance Framework \\
\hline \multicolumn{1}{|c|}{ Climate Change Policies/Plans/Projects } \\
\hline 1. & $\begin{array}{l}\text { Nepal's Initial National Communication (INC) of the United Nations } \\
\text { Framework Conventions on Climate Change (UNFCCC), 2004 }\end{array}$ \\
\hline $\mathbf{2 .}$ & National Adaptation Programme of Action (NAPA), 2010 \\
\hline 3. & Poverty-Environment Initiatives (PEI), 2010 \\
\hline 4. & Pilot Programme for Climate Resilience (PPCR), 2010 \\
\hline 5. & Climate Adaptation Design Project-Nepal (CADP-N), 2010 \\
\hline $\mathbf{6 .}$ & Local Adaptation Plans of Action (LAPA), 2011 \\
\hline 7. & $\begin{array}{l}\text { National Planning Commission (NPC) Climate Resilient Planning } \\
\text { (CRP), 2011 }\end{array}$ \\
\hline $\mathbf{8 .}$ & National Climate Change Policy (CCP), 2011 \\
\hline 9. & Second National Communication to the UNFCC, 2011 \\
\hline 10. & Intended National Determined Contributions (INDCs), 2015 \\
\hline $\mathbf{1 1 .}$ & National Adaptation Plan (NAP), 2015 (on the process) \\
\hline 12. & Nepal Climate Change Support Programme, 2015 \\
\hline 13. & National REDD+Strategy 2015 \\
\hline 14. & Low Carbon Economic Development Strategy (LCEDS), 2015 \\
\hline
\end{tabular}

Source: Sova and Chaudhary, [16] modified by the authors

Almost all experts agreed on the progressive and positive development of the climate change policies in Nepal particularly focusing on climate change adaptation and promoting climate smart development, as number of policies have been formulated in recent years. However, few experts recognized the infancy or stagnant state of policies, which still need to back up with scientific data and information and effective implementation to be sustainable. They also highlighted the lack of resources and capacities to implement the policies and the priority programmes/projects at the local level. MoE [14], itself, estimated a total cost of \$ 350 million to implement the NAPA priorities, whereas Oxfam [17] argued for the requirement of over $\$ 1$ billion to implement NAPA priorities effectively. Likewise, Bird [18] argued that the financial planning, particularly on costing public sector investments, is not well developed in climate policies and planning in Nepal.

An expert in the survey revealed the initiation of the GoN to develop separate budget code for climate change in national budget to track the expenditure related to climate change actions and activities. Baral and Chhetri [19] also disclosed the separate budget code in their paper, which was introduced by the Ministry of Finance based on the pilot project conducted by National Planning Commission and the United Nations Development Programme (UNDP) in 2012. NPC [20] revealed the effective cooperation among 11 ministries in Nepal in the process of developing 
the methodology for tracking climate expenditure. The budget code and tracking is concentrate on public finance only, not for tracking climate investments of community based organizations, international/non-governmental organizations (I/NGOs). However, NPC [21] believes that this code ensures the transparency and accountability through systematic tracking of public finance in all sectors and strengthen the link between policy objectives and resource allocation.

One of the main issues raised by the experts on climate policies is the formulation process which was highly driven by the guidance of international bodies and mechanisms rather than the country driven process and national needs and priorities. Most of climate policies and plans/strategies developed in Nepal are in the response of response to the international negotiations, agreements and treaties, except the LAPA framework. Tiwari et al., (2014) agreed that GoN developed and proclaimed adaptation and mitigation policies in response to international climate regime. Helvetas Nepal [8] also reinforced that some policies are formulated to fulfill the domestic needs whereas others guided by the international agreements and treaties. Ojha et al., [9] also emphasized on the adaptation policies which are largely driven by the international actors and their generic world views. Most of the environmental related policies in Nepal are guided by the international treaties that Nepal is signatories such as Kyoto Protocol. However, climate change policy should be an outcome of domestic necessities as Nepal is highly vulnerable to the adverse climate change impacts. UNFCCC defined several steps to develop NAPA in inclusive, participatory, action oriented, country driven and responsive to climate change adaptation [22].

Another major issues raised was the seriousness of the government in implementation of these policies. Climate change is not a main national priority despite being highly vulnerable to the climate change impacts. One of the core reason is the unstable government and government priorities. For instance, the Ministry is repeatedly changed and merged with different other ministries when the political leadership has changed in the government. It used to be Ministry of Science, Technology and Environment (MoSTE) last year, but now it became Ministry of Population and Environment (MoPE). Additionally, the experts revealed the lack of implementing bodies at district and lower administrative units under this ministry, which was supported by Helvetas Nepal [8] and Tiwari et al., [2]. There is lack of elected government bodies at the local level for more than 15 years, thus, no mechanisms for coordination among the stakeholders due to lack of responsibilities and ownerships. Additional issues identified by the experts are capacities of the ministries, available resources and collaboration between and among the ministries and departments for effective implementation of policies, plans and strategies. Most of the experts realized the necessity of sensitization, awareness and education on climate policies to the all sectors including farmers, urban dwellers, academia, so that there will be demand for good policy formulation, implementation and reform. 
Regmi \& Bhandari [4] also found the lack of sensitization and awareness among the local communities.

One additional issue identified by the experts is lack of clarity on fund disbursement mechanisms, despite the agreement of $80 \%$ budget allocation at the local level and the budget code was developed. Helvetas Nepal [8] also identified the issue of no differentiation in fund disbursement (up to 80\%) for the mitigation and adaptation programmes. Tiwari et al., [2] underlined on lack of implementation capacity to utilize the $80 \%$ fund at the local level, since there is no any elected body at the local level. Additionally, NPC [21] has identified the problem in climate financing because of the fact that the ministries within the government have their own development agenda, priorities and responsibilities that dissuade them to be concerned about climate change issues.

\subsection{Roles, responsibilities and collaboration among ministries, departments and other stakeholders}

Climate change is a cross cutting issue, impacting multiple sectors and actors. Thus, the collaboration among sectoral ministries, including sectoral/thematic and crosscutting sectors is crucial for effective implementation of the climate change policies, plans and frameworks. Most of the experts also agreed on specific roles of sectoral ministries to develop and implement sectoral policies. Ministry of Population and Environment (MoPE) is the focal ministry, which is responsible for policy formulation, coordination and international negotiation. Especially, Ministry of Federal Affairs and Local Development (MoFALD) is responsible for the implementation of adaptation plans and integration to the local development planning. The roles, responsibilities and collaboration among the ministries and departments as stipulated by the climate experts in Nepal is presented in table 2. Furthermore, most of the experts emphasized on mainstreaming climate change in the sectoral policies and plans. However, most the ministries haven't successfully integrated the climate change issues in their policies, plans/strategies and frameworks.

Experts claimed the strong vertical linkage and coordination in most of the ministries, except MoPE, however the horizontal linkages among competent ministries are comparatively weak. Some experts raised the issues of capacity and confidence of MoPE in collaboration, coordination and managing the climate funds. Regmi and Bhandari [4] also argued that the ministry hasn't yet confidently played its role in coordinating the ministries and manage the climate funds. They further argued on the lack of trust, clarity on the roles and responsibilities and coordination among ministries, donors, governments and civil societies in terms of capacities, transparency and accountability as the constraints in their paper. 
Table 2: Summary of the roles and responsibilities as defined by the climate experts

\begin{tabular}{|c|c|c|}
\hline S.N. & Ministries/Departments & Roles and Responsibilities \\
\hline 1. & $\begin{array}{l}\text { Ministry of Population } \\
\text { and } \\
(\mathrm{MoPE})\end{array}$ & $\begin{array}{l}\text { Focal Ministry, Policy formulation for climate } \\
\text { change, overall coordination among the } \\
\text { agencies at central level }\end{array}$ \\
\hline 2. & $\begin{array}{lr}\text { Ministry of } & \text { Federal } \\
\text { Affairs and } & \text { Local } \\
\text { Development } & \\
(\text { MoFALD) } & \\
\end{array}$ & $\begin{array}{l}\text { Coordination with local government for } \\
\text { effective execution of climate change activities } \\
\text { at local level }\end{array}$ \\
\hline 3. & $\begin{array}{l}\text { Ministry of Finance } \\
(\mathrm{MoF})\end{array}$ & $\begin{array}{l}\text { Focal Ministry for climate finance and } \\
\text { responsible for integrating climate finance into } \\
\text { development plans and budgets }\end{array}$ \\
\hline 4. & $\begin{array}{l}\text { Ministry of Forests and } \\
\text { Soil } \quad \text { Conservation } \\
\text { (MoFSC) }\end{array}$ & $\begin{array}{l}\text { Policy Formulation, integration and } \\
\text { implementation of climate change issues into } \\
\text { forestry policies, strategies and plans }\end{array}$ \\
\hline 5. & $\begin{array}{l}\text { Ministry of Agricultural } \\
\text { Development (MoAD) }\end{array}$ & $\begin{array}{l}\text { Policy Formulation, integration and } \\
\text { implementation of climate change issues into } \\
\text { agricultural policies, strategies and plans }\end{array}$ \\
\hline 6. & $\begin{array}{l}\text { National Planning } \\
\text { Commission (NPC) }\end{array}$ & $\begin{array}{l}\text { Policy direction and Integration of climate } \\
\text { change issues into national level development } \\
\text { policies, plans and budgeting process }\end{array}$ \\
\hline 7. & $\begin{array}{l}\text { Department of Forests, } \\
\text { Soil, Agriculture and } \\
\text { others }\end{array}$ & $\begin{array}{l}\text { Implementation of climate responsive sectoral } \\
\text { policies, plans in coordination with local and } \\
\text { national stakeholders including I/NGOs for } \\
\text { climate change adaptation and mitigation } \\
\text { activities through sectoral committees. }\end{array}$ \\
\hline 8. & $\begin{array}{l}\text { Climate change council } \\
(\mathrm{CCC})\end{array}$ & $\begin{array}{l}\text { Coordination for effective policy } \\
\text { implementation }\end{array}$ \\
\hline
\end{tabular}

\subsection{Factors for effective implementation of policies, plans, programs and strategies}

Based on the response of the experts on factors affecting the effective implementation of the climate policies, plans/strategies and frameworks, it can be comprehended that political and institutional factors are highly influential. Because of political instability, the MoPE, which is focal ministry of climate change policies and plans/strategies, is not stable and take stand and initiate to grow itself to address the emerged issues. Furthermore, the ministry lacks the human resources and institutional set up for effective implementation of the policies, plans/strategies and frameworks. There is a huge gap in institutional arrangement, capacity to implement and mechanisms for adaptation policies and programmes at local level [23]. One of the experts revealed that the national politics has given minimum priority to the mandates of MoPE. Considering the situation, Tiwari et al., [2] 
proposed to revisit the structure of $\mathrm{MoPE}$, being a responsible ministry for the result oriented implementation of climate change policies, plans/strategies and frameworks. Furthermore, there is a lack of elected local bodies and capacities to absorb and implement the policies at the local level.

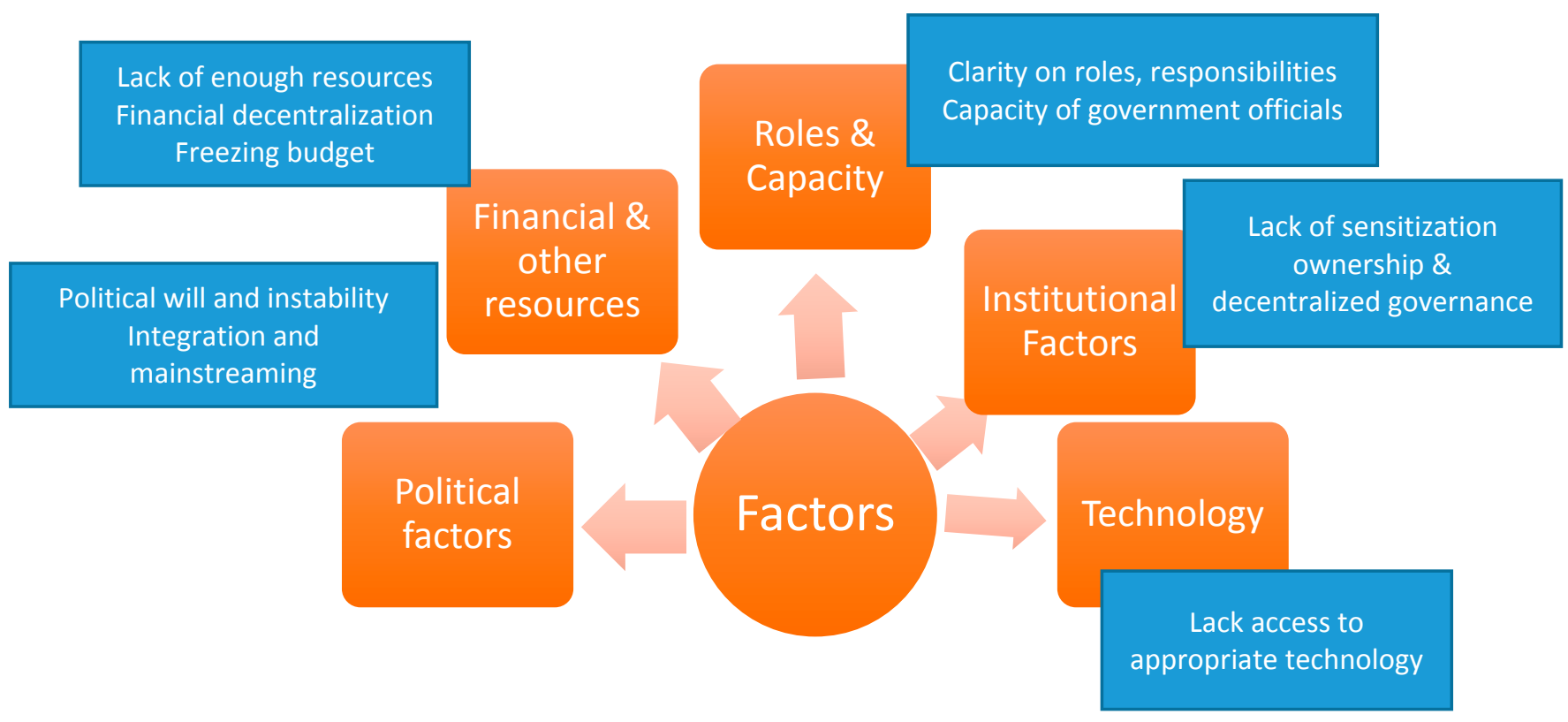

Figure 4: Factors affecting effective implementation of climate policies, plans/strategies and frameworks in Nepal

\subsection{Indicators for effectiveness of climate change adaptation policies, plans and strategies}

It is revealed that there is no national level agreed framework or indicators to measure the progress on climate change policies, plans/strategies and frameworks based on the responses of the climate experts. National climate change policy hasn't even reflected the priorities and targets to be achieved. In most of the cases, public and private sectors emphasize on quantitative indicators to measure and manage the success of policies and plans/strategies implementation. However, the climate policies, plans/strategies and frameworks lack such indicators. Depending on the responses of the experts, the indicators are categorized into process indicators and outcome indicators as presented in the figure 5 . 


\section{Process indicators}

- Flexible, participatory and

inclusiveness in the formulation

process

- $\quad$ Reduced migration and health related

issues because of climate change

- Time bound goals and targets have been achieved or not

- Collaborative and collective processes following bottom up and top-down approaches

- Integration to the national and local plans and sectoral plans

- $\quad$ Responsive to the local contexts and scenarios addressing the climate issues
Outcome indicators

- Increased adaptive capacities of the communities with minimum or reduced loss of lives and impacts of climate change

- Farmers managed to change in agriculture by themselves based on changes in weather and climate

- Farmers developed their own strategies

- Increased food security

- $\quad$ Reduced vulnerabilities and risks to the communities; Minimum impacts.

Figure 5: Process and outcome indicators of effective implementation of climate change policies, plans/strategies and frameworks

According to Cust [24], the policy indicators are necessary for the outputs and outcomes as presented in this paper. However, he hasn't mentioned about the process indicators.
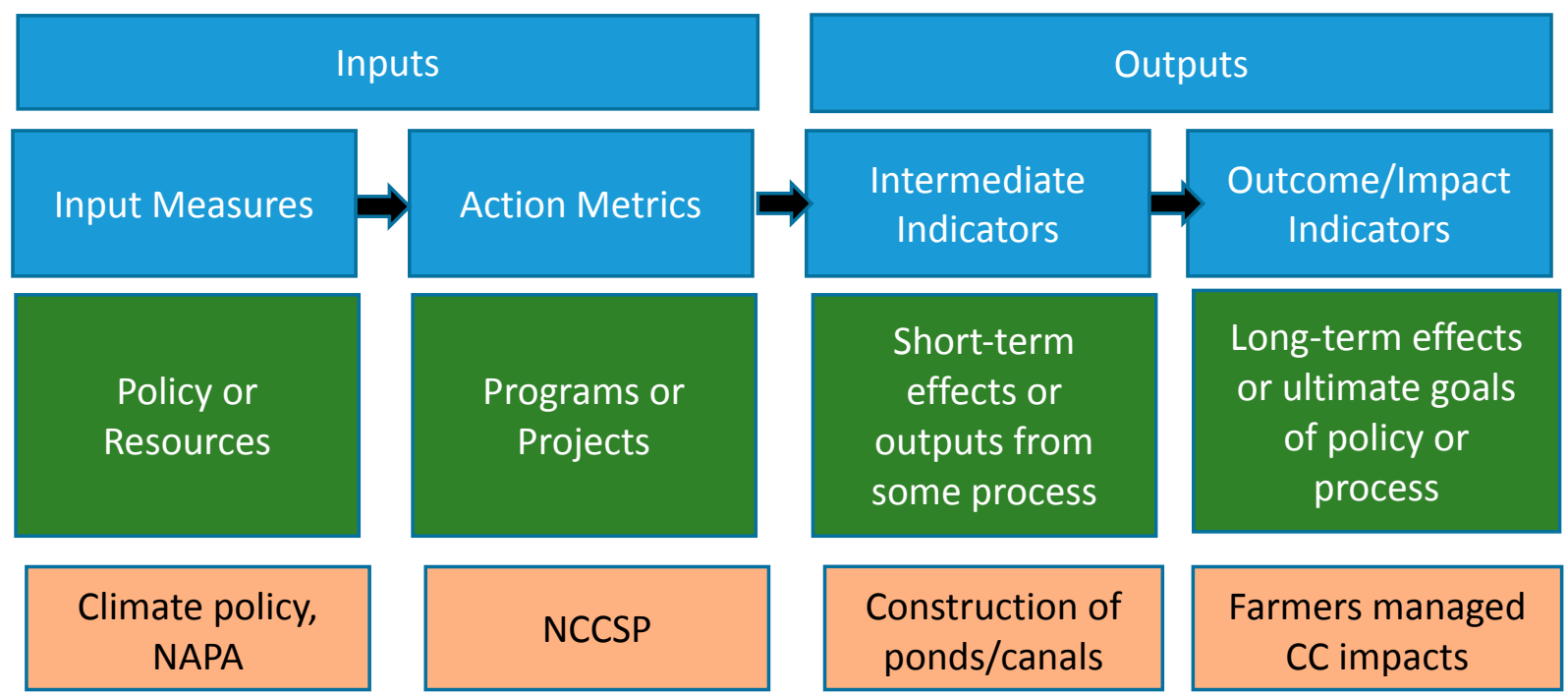
Farmers managed CC impacts

Figure 6: Climate policy indicators, inputs vs outcome indicators as defined by Cust [24]

\section{Conclusions and way forward}

Most of the climate experts believe that climate change policies, plans/strategies, frameworks are progressive and advancing in Nepal except some experts think it still an infant and stagnant stage. Some experts have even emphasized that the policies, plans/strategies should be dynamic in nature with periodic review and revision. These policies, plans/strategies and frameworks are inter-related in hierarchical order, though not always follow the same order. Even in Nepalese context, NAPA was formulated and endorsed before the national climate change 
policy. Many actors and stakeholders are engaged/involved in formulation and implementation of these policies and plans/strategies, however collaboration and cooperation is not always effective. One of the main issue raised by the experts was the policy formulation process highly driven by the international negotiations and agreements more than the national requirements. Local people and communities at the grass root levels are not aware of the policies and plans/strategies, though the government and some experts also claimed that the policies and plans/strategies formulation processes were participatory, inclusive, flexible and responsive.

It is important to formulate these policies, plans/strategies, frameworks and projects. It is far more important to effectively implement them to minimize the climate related issues at the local and national levels. However, the experts are still concerned about the resources required and capacities of MoPE even for effective collaboration and implementation of these policies, plans/strategies and frameworks. The ministry itself is not stable in Nepalese context because of frequent changes in the governments which also impacts on the leadership and number of technical staffs in the ministry. It is realized that the political and institutional factors are dominating in climate policies and plans/strategies in Nepal. Based on the responses, the process and outcome indicators are identified, which are very broad indicators such as reducing the vulnerabilities of the vulnerable population as an important outcome indicator.

This survey has generated the general picture of state of climate policies, plans/strategies and frameworks including the roles and responsibilities of ministries, departments and other stakeholders, factors and subjective indicators based on the views and observations of climate experts in Nepal. Based on the findings, the second phase of the survey will be designed which will be more specific to climate change adaptation especially, NAP, NAPA, LAPA including the funding arrangement ( $80 \%$ of the total fund) at the local level. This survey has been planned for 2-3 phases survey with the climate experts in Nepal. It is realized that all the experts are super busy with their respective duties and responsibilities.

\section{Acknowledgements}

The authors would like to acknowledge the valuable contributions and support of the climate experts in Nepal, who have responded the questionnaire despite their busy and hectic schedule. 


\section{References}

1. Malla, G. Climate change and its impact on Nepalese Agriculture. The Journal of Agriculture and Environment. 2008. 9: 62-71.

2. Tiwari, K. R.; Rayamajhi, S.; Pokharel, R. K.; Balla, M. K. Does Nepal's climate change adaptation policy and practices address poor and vulnerable communities? Journal of Law, Policy and Globalization. 2014. 23: 28-38, ISSN 2224-3240 (Paper), ISSN 2224-3259 (online)

3. MoSTE, National adaptation plan formulation process. Launching Workshop Proceeding. Government of Nepal, Ministry of Science, Technology and Environment, Climate Change Management Division, Kathmandu, 18, September 2015.

4. Regmi, B. R.; Bhandari, D. Climate change governance and funding dilemma in Nepal. TMC Academic Journal. 2012. 7 (1): 40-55

5. Webesik, C.; Thapa, M. Nepal climate change and security factsheet. United Nations University (UNU-IAS). www.ias.unu.edu/sdg, 2008. (Accessed in 20 November 2016)

6. MoPE, Intended Nationally Determined Contributions (INDC): Committed to the UNFCCC Secretariat in February 2016. Government of Nepal, Ministry of Population and Environment, Kathmandu. 2016.

7. Maplecroft. Net Limited. Risk calculator and dashboards: Climate change Vulnerability Index 2011. https://maplecroft.com/about/news/ccvi.html (Accessed in 21 December 2016)

8. Helvetas Nepal. Nepal's climate change policies and plans: Local communities' perspective. Environment and Climate Series 2011/1. Helvetas Nepal - Swiss Inter-cooperation and Rights Resources Institute (RRI). 2011.

9. Ojha, H.R.; Ghimire, S.; Pain, A.; Nightingale, A.; Khatri, D.B.; Dhungana, H. Policy without politics: Technocratic control of climate change adaptation policy making in Nepal. Climate Policy. 2015. 16 (4): 415-433. Doi: 10.1080/14693062.2014.1003775

10. Maharjan, S. K.; Maharjan, K. L. Review of climate policies and roles of institutions in the policy formulation and implementation of adaptation plans and strategies in Nepal. Journal of International Development and Cooperation. 2016. 23 (1 \& 2): 1-14. (Accessed on 18 October 14, 2016 in http://s-en.hiroshima-

u.jp/upload files/download files/4.Shree\%20Kumar\%20MAHARJAN\%20an d\%20Keshav\%20Lall\%20MAHARJAN.pdf)

11. Nepal Climate Change \& Development Portal. Climate change networks and communities. Ministry of Science, Technology and Environment. http://www.climatenepal.org.np (Accessed on 18 October 2016)

12. Edvardsen, M. A Chinese box model of planning, Conference paper. 1995. DOI: 10.13140/RG.2.1.1493.4484. https://www.researchgate.net/publication/283285925 (accessed on Dec 17 2016) 
13. Peniston, B. A review of Nepal's local adaptation plans of action (LAPA). High Mountains Adaptation Partnership. 2013. The Mountain Institute and USAID.

https://www.climatelinks.org/sites/default/files/asset/document/NepalLAP As Stocktaking TMI-Peniston-FINAL.pdf (accessed on 7 December 2016)

14. MoE. National adaptation program of actions (NAPA) to climate change. Ministry of Environment, Government of Nepal. 2010.

15. Sherpa, P. D.; Sherpa, P.; Ghale, K.; Rai. Y. Locating Indigenous Peoples Perspective in REDD+ Implementation in Nepal. Nepal Federation of Indigenous Nationalities (NEFIN)

16. Sova, C. A.; Chaudhary, A. S. State of agricultural climate change adaptation policy in Nepal. Working Paper No. 44. CGIAR Research Program on Climate Change, Agriculture and Food Security (CCAFS), Copenhagen, Denmark. Available online at: www.ccafs.cgiar.org. 2013.

17. Oxfam. Minding the money: Governance of climate change adaptation finance in Nepal, Oxfam Nepal. 2011.

18. Bird, N. The future of climate finance in Nepal. Overseas Development Institute, London. 2011

19. Baral, P.; Chhetri, R. P. Finding the money: A stocktaking of climate adaptation finance and governance in Nepal. Oxfam Country Office Nepal. 2014.

20. NPC. Climate change budget code, Documenting the national process of arriving at multi-sectoral consensus, Criteria and Method. Government of Nepal, National Planning Commission with support from UNDP/UNEP, Kathmandu, Nepal. 2012.

21. NPC. Climate change budget code, Application Review. Government of Nepal, National Planning Commission with the support of UNDP/UNEP, Kathmandu Nepal. 2013.

22. Sharma, S. K. The political economy of climate change governance in Himalayan region of Asia: A case study of Nepal. Procedia Social and Behavioral Sciences. 2011. 11: 129-140. Doi: 10.1916/j.sbspro.2011.03.030

23. Tiwari, K. R.; Balla, M. K.; Pokharel, R. K.; Rayamajhi, S. Climate change impact, adaptation practices and policy in Nepal Himalaya. Climate change and Development Policy, 28-29 September 2012. Helsinki, Finland, UNUWIDER Conference, United Nations University

24. Cust, J. Using Intermediate indicators: Lessons for climate policy. Climate policy. 2009. 9 (5): 450 - 463, ISSN 1469-3062, ISBN 978-1-84407-872-1 